\title{
Pemanfaatan Education Information Management System (Emis) dalam Sistem Pelaporan Lembaga Pendidikan Kementerian Agama Kabupaten Tuban
}

\author{
Yuliana Tri Handayani, Anisha Choirul Nimah, Zulli Nurrita \\ Muhammad Nuril Huda
}

UIN Sunan Ampel, Surabaya - Indonesia | yulianatrihandayani9@gmail.com

\begin{abstract}
Abstrak: Aplikasi EMIS merupakan salah satu jenis aplikasi pendataan pendidikan Islam yang dikembangkan oleh Subbag Sistem Informasi, Bagian Perencanaan dan Sistem Informasi, Setditjen Pendidikan Islam (Tim EMIS Pendis Pusat) untuk mendukung proses validasi data EMIS yang dijaring dari setiap sumber data. Peran EMIS disini adalah sebagai sumber data yang dapat digunakan sebagai pendukung dalam pengambilan keputusan atau kebijakan dan juga dalam sistem pelaporan lembaga. Dalam penelitian ini, tujuan utamanya adalah untuk mengetahui bagaimana pemanfaatan EMIS dalam sistem pelaporan lembaga di Kementerian Agama Kabupaten Tuban. Metode yang digunakan yakni metode kualitatif, yang nantinya hasil penelitiannya berbentuk narasi. Subjek dalam penelitian ini adalah operator EMIS tingkat Kabupaten Tuban, kepala bagian PD Pontren Kementerian Agama Kabupaten Tuban, dan staf bagian pendataan PD Pontren Kementerian Agama Kabupaten Tuban.
\end{abstract}

Keywords: emis, sistem pelaporan

\section{Pemdahuluan}

Perkembangan Teknologi Informasi dan Komunikasi di bidang pendidikan di era 4.0 saat ini semakin pesat. Dalam meningkatkan mutu sumberdaya manusia saat ini Indonesia memiliki potensi yang sangat baik. Salah satunya dengan adanya sistem informasi pendidikan yang ada dapat menunjang kinerja pegawai dalam melakukan aktivitas kepegawaian. Pemanfaatan manajemen berbasis TIK ini sangat penting karena dalam mengambil kebijakan harus disesuaikan dengan kebutuhan yang didasarkan pada data yang benar dan akurat. 
Sistem Informasi Manajemen (SIM) merupakan sistem informasi yang menghasilkan hasil keluaran dengan masukan dan berbagai proses yang diperlukan untuk memenuhi tujuan tertentu dalam suatu kegiatan manajemen. Menurut O'Brien, Sistem Informasi Manajemen (SIM) merupakan suatu sistem terstruktur yang menyediakan informasi untuk mendukung kegiatan operasional, manajemen dan fungsi pengambilan keputusan dari suatu organisasi.

O'Brien menyatakan bahwa tujuan Sistem Informasi Manajemen (SIM) merupakan (1) menyediakan informasi yang digunakan di dalam perhitungan harga pokok jasa, produk, dan tujuan lain yang diinginkan manajemen; (2) menyediakan informasi yang digunakan dalam perencanaan, pengendalian, pengevaluasian dan perbaikan berkelanjutan; (3) menyediakan informasi untuk pengambilan kebijakan.6

Pemanfaatan TIK oleh masyarakat sekarang ini sudah menjadi biasa, tidak lagi menjadi impian yang sulit diwujudkan, termasuk pemanfaatannya di dunia pendidikan. Pemanfaatan teknologi informasi dan komunikasi dalam bidang pendidikan sudah tidak menjadi bagian yang dapat dipisahkan, Penerapan sistem informasi manajemen pendidikan yang harus tepat sasaran agar pelaksanaan dan pemanfaatannya berjalan sesuai dengan kepentingan dan tujuan bidang pendidikan. Yang bertanggung jawab dalam pelaksanaan pendidikan Agama madrasah dan sekolah dalam pendataan yang menggunakan sistem informasi manajemen pendidikan atau yang biasa dikenal dengan sebutan EMIS (Education Management Information System) yaitu Kementrian Agama.7 EMIS (Education Management Information System) merupakan sebuah metode manajemen formal dalam penyediaan informasi pendidikan yang akurat dan tepat waktu sehingga proses pengambilan keputusan, pengembangan proyek, perencanaan, dan fungsi-fungsi manajemen pendidikan lainnya dapat dilaksanakan secara efektif. Sistem Informasi Manajemen Pendidikan atau EMIS merupakan sebuah informasi dan dokumentasi yang terorganisasi dalam melakukan pengumpulan, penyimpanan, pengolahan 
analisis, dan penyebaran informasi yang dipergunakan dalam administrasi dan perencanaan pendidikan.

Dapat disimpulkan bahwa sistem informasi manajemen pendidikan yang mengatur data dan informasi untuk disimpan, dikelola, dianalisis, dan digunakan dalam pengambilan keputusan pendidikan.

Adapun tujuan dari pembangunan dan pengembangan EMIS di lingkungan Direktorat Jenderal Pendidikan Islam antara lain: 1) menyediakan data dan informasi yang dibutuhkan dalam perumusan kebijakan, perencanaan penyelenggaraan pendidikan, pengembangan poyek, penyusunan anggaran dan pengambilan keputusan. 2) menyediakan dan mendukung pimpinan dengan data terbaru yang diperlukan untuk membuat perencanaan dan pengambilan keputusan yang lebih efektif dalam skala regional dan nasional. 3) membantu percepatan penyelenggaraan otonomi daerah dengan menyajikan data secara regional (propinsi dan kabupaten/kota) sehingga daerah dapat dengan mantap menyusun rencana pembinaan dan penyelenggaraan pendidikan di tingkat propinsi dan kabupaten/kota dengan mempertimbangkan aspek equity (kesetaraan), quality (kualitas), efficiency (efisiensi), dan effectiveness (efektivitas). 8

Sistem Informasi Manajemen Pendidikan atau EMIS, digunakan sebagai penunjang kegiatan fungsi manajemen seperti perencanaan, pengorganisasian, pelaksanaan, pengawasan dalam rangka menunjang tercapainya tujuan dan tujuan fungsi operasional dalam organisasi pendidikan. Dengan harapan agar organisasi pendidikan menjadi transparan dan akuntabel.9

Dengan pemanfaatan system Emis ini diharapkan data-data yang masuk dapat lebih valid dan seiring berjalannya waktu dapat diperbaharui atau di update sehingga dapat dipergunakan sebagai dasar pengambilan keputusan. Data-data yang sudah akurat (valid) dibutuhkan sebagai bahan pertimbangan yang digunakan dalam setiap pengambilan kebijakan ataupun pengambilan keputusan.

Kementerian Agama Republik Indonesia (Kemenag RI) adalah kementerian dalam pemerintah Indonesia yang membidangi urusan agama. Kantor Kementerian Agama dibagi menjadi tiga wilayah 
yakni kantor pusat, kantor wilayah, dan kantor kabupaten. Kementerian Agama Kabupaten Tuban merupakan salah satu kantor kementerian tingkat kabupaten. Prospek kerja di kantor Kemenag Tuban terbagi menjadi enam bidang, diantaranya yaitu bidang Bimbingan Masyarakat Islam (BIMSYAR), bidang Penyelenggaraan Haji dan Umrah, bidang Pendidikan Madrasah (PENDMA), bidang Pendidikan Diniyah dan Pondok Pesantren (PD Pontren), bidang Pendidikan Agama Islam (PAIS), dan bidang Penyelenggaraan Zakat dan Wakaf.

Bidang Pendidikan Diniyah dan Pondok Pesantren Kementerian Agama Kabupaten Tuban adalah salah satu bidang yang melayani segala urusan yang berkaitan dengan lembaga pendidikan islam baik formal maupun non formal yang meliputi Pondok Pesantren, Pendidikan Diniyah Formal, Diniyah Takmiliyah, Taman Pendidikan Al- Qur'an (TPQ), Pendidikan Kesetaraan Pondok Pesantren Salafiyah (PKPPS), Muadalah, dan Majlis Taklim. Dalam pendataan lembaga-lembaga tersebut, PD Pontren sudah menggunakan aplikasi Education Information Management System (EMIS). Dengan menggunakan EMIS, bidang PD Pontren akan lebih mudah dalam mengakses data-data terkait lembaga pendidikan Islam yang dinaunginya. Data EMIS juga berguna ketika hendak mengambil keputusan, seperti ketika akan mengadakan acara sosialisasi untuk lembaga diniyah se-kabupaten Tuban, maka jumlah peserta sosialisasi tersebut bisa dilihat dari data EMIS. Selain itu, EMIS juga digunakan sebagai acuan dalam sistem pelaporan bidang PD Pontren. Dengan latar belakang tersebut maka fokus penelitian jurnal ini adalah pemanfaatan emis dalam system pelaporan lembaga kementerian agama kabupaten Tuban.

\section{Metodologi}

Penelitian tentang pemanfaatan emis dalam sistem pelaporan lembaga kementerian agama kabupaten Tuban merupakan jenis penelitian kualitatif. Penelitian kualitatif adalah sebuah riset yang lebih cenderung menggunakan analisis pendekatan deduktif dan bersifat deskriptif. Dalam pelaksanaannya proses penelitian dan pemanfaatan landasan teori cenderung lebih menonjol dilakukan agar fokus penelitian sesuai dengan fakta dilapangan.10 
Subjek penelitian ini meliputi kepala seksi Pendidikan Diniyah dan Pondok Pesantren (PD Pontren) Kementerian Agama Kabupaten Tuban, operator EMIS lembaga dibawah naungan seksi Pendidikan Diniyah dan Pondok Pesantren (PD Pontren) tingkat kabupaten, dan bagian administrasi seksi pendidikan Tuban. Waktu penelitian mulai 24 Agustus 2020 sampai 11 Oktober 2020. Lokasi penelitian ini berada di Kantor Kementerian Agama Kabupaten Tuban. Teknik pengumpulan data penelitian ini menggunakan teknik wawancara dan observasi.

Teknik analisis data dalam penelitian ini meliputi reduksi data, penyajian data, dan kesimpulan data. Berikut prosedur analisis dara, meliputi :

\section{Pengumpulan Data (Data Collection)}

Data-data yang diperoleh berasal dari narasumber di Bidang Pendidikan Diniyah dan Pondok Pesantren Kementerian Agama Kabupaten Tuban. Pencatatan dilakukan berdasarkan hasil wawancara. Di buat dengan bentuk catatan kecil. Catatan tersebut kemudian didiskripsikan menjadi sebuah narasi deskriptif dan jurnal reflektif atas fenomena yang terjadi dilapangan.

\section{Reduksi Data (Reduction)}

Reduksi data merupakan proses pemilihan, pemusatan perhatian, pada penyederhanaan, pengabsrakkan dan transformasi data kasar yang muncul dari catatan lapangan. Reduksi data merupakan wujud analisis yang menajamkan, mengklafikasikan, mengarahkan, membuang data yang tidak berkaitan dengan aktivitas kelembagaan di Bidang Pendidikan Diniyah dan Pondok Pesantren Kementerian Agama Kabupaten Tuban. Selanjutnya dibuat ringkasan, pengkodean, penelusuran tema-tema, membuat catatan kecil yang dirasakan penting.

\section{Penyajian Data (Display)}

Langkah sesudah mereduksi data adalah penyajian data. Teknik penyajian data dalam kualitatif adalah berupa uraian, bagan, hubungan antar katagori, dan sejenisnya. Pada tahap ini disajikan data hasil temuan dilapangan dalam bentuk teks naratif.

\section{Penarikan Kesimpulan dan Verifikasi}


Dalam analisis data kualitatif menyimpulkan dan kesimpulan verifikasi. Dengan demikian kesimpulan dalam penelitian kualitatif mungkin dapat menjawab rumusan masalah yang dirumuskan pada awal penelitian.

\section{Hasil dan Pembahasan}

Sistem Informasi Manajemen (SIM) adalah rangkaian terorganisasi dari sejumlah bagian/komponen yang secara bersamasama berfungsi atau bergerak menghasilkan informasi untuk digunakan dalam manajemen lembaga.11 Dalam rangka membangun informasi yang handal, dibutuhkan Sistem Informasi Manajemen (SIM) yang mampu menampung dan mengolah data serta menghasilkan informasi yang tepat dan akurat setiap saat. Tanpa dukungan SIM yang tangguh, maka akan sulit bagi organisasi yang baik akan terwujud, karena SIM menolong lembaga-lembaga bidang apapun dalam mengintegrasikan data, mempercepat dan mensistematisasikan pengolahan data, meningkatkan kualitas informasi, mendorong terciptanya layananlayanan baru, meningkatkan kontrol, mengotomatisasikan sebagian pekerjaan rutin, menyederhanakan alur registrasi atau proses keuangan, dan lain sebagainya.

Sistem informasi manajemen yang digunakan dalam bidang PD Pontren adalah aplikasi Education Management Information System (EMIS). Aplikasi EMIS merupakan salah satu jenis aplikasi pendataan pendidikan Islam yang dikembangkan oleh Subbag Sistem Informasi, Bagian Perencanaan dan Sistem Informasi, Setditjen Pendidikan Islam (Tim EMIS Pendis Pusat) untuk mendukung proses validasi data EMIS yang dijaring dari setiap sumber data. Aplikasi ini digunakan untuk memberikan pelayanan khususnya kepada lembaga pendidikan islam mulai dari pendaftaran lembaga, update profil lembaga, hingga perpanjangan lembaga. Berikut merupakan tampilan halaman depan dari EMIS : 
Implementasi Manajemen

Gambar. Laman Depan Untuk Operator Aplikasi EMIS ketika log in

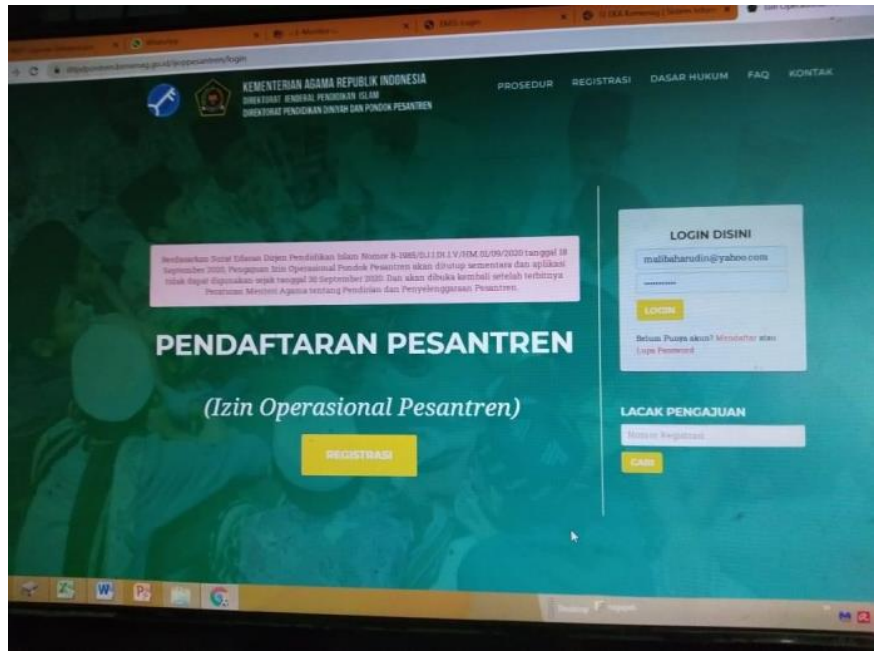

Gambar. Laman Depan Untuk Lembaga ketika akan mendaftarkan diri di Aplikasi EMIS

Secara teknis, sejak Februari 2002 EMIS resmi menjadi "Bagian Data dan Informasi Pedidikan", oleh karena itu kegiatan pendataan, pengolahan, pelaporan, pelayanan dan sosialisasi data serta 
informasi pendidikan menjadi tanggung jawab bagian tersebut. Dengan terbentuknya kelembagaan tersebut, penting artinya agar selalu dapat memenuhi seluruh kebutuhan data dan informasi bagi pembangunan dan pengembangan lembaga pendidikan Islam di Indonesia.

Secara operasinal EMIS, diberlakukan berdasarkan Keputusan Direktur Jenderal Pendidikan Islam Nomor J.I/46/2009. Tentang Pedoman Mekanisme Pendataan Lembaga Pendidikan Islam. Dalam kebijakan tersebut, dijelaskan bahwa tujuan Perancangan dan Pengembangan Education Management Information Sistem (EMIS) di lingkungan Direktorat Jenderal Pendidikan Islam diharapkan mampu menjadi jalan keluar atas permasalahan klasik yang selama ini terjadi di Kementerian Agama, yaitu ketidaktersediaan data dan informasi yang memadai tentang dunia pendidikan islam secara nasional. Untuk mencapai hasil yang maksimal, EMIS memerlukan persiapan yang baik terutama dari segi kemampuan dasar manajemen, ketersediaan instrumen statistik yang akan dipergunakan untuk menghimpun data, serta berbagai fasilitas pengolahan data baik secara komputerisasi maupun manual untuk memudahkan proses pengolahan data hingga menjadi informasi yang bermanfaat. 12

Fungsi dari EMIS sendiri yaitu memberikan pelayanan pendaftaran operator EMIS tingkat lembaga, pelayanan perubahan akun dan password lembaga, serta perekapan data lembaga. Lembaga yang dimaksud merupakan lembaga dibawah naungan PD Pontren yang meliputi Pondok Pesantren, Pendidikan Diniyah Formal, Diniyah Takmiliyah, Taman Pendidikan Al-Qur'an (TPQ), Pendidikan Kesetaraan Pondok Pesantren Salafiyah (PKPPS), dan Majlis Taklim.13

Berdasarkan data EMIS dapat disimpulkan bahwa data lembaga pendidikan Islam dibawah naungan seksi Pendidikan Diniyah dan Pondok Pesantren Kementerian Agama Kabupaten Tuban di 20 kecamatan meliputi : 104 lembaga pondok pesantren; 2 lembaga muadalah yang hanya berada di kecamatan Soko; 10 lembaga pendidikan kesetaraan tingkat wustho dan ulya yang diantaranya berada di kecamatan Senori, Singgahan, Plumpang, Widang, 
Merakurak, Tambakboyo, dan Jatirogo; 6 lembaga pendidikan diniyah formal tingkat wustho dan ulya yang diantaranya berada di kecamatan Singgahan, Soko, dan Rengel; 1157 lembaga Taman Pendidikan Al-Qur'an (TPQ); dan 499 lembaga diniyah takmiliyah yang mencakup 360 lembaga tingkat awaliyah, 133 lembaga tingkat wustho, dan 6 lembaga tingkat ulya.14

Keseluruhan lembaga tersebut bisa terdata pada aplikasi EMIS, tentunya dengan melalui beberapa tahapan diantaranya : lembaga melakukan registrasi melalui laman http://emispendis.kemenag.go.id/emis_pontren, dalam proses tersebut lembaga perlu memenuhi beberapa persyaratan pendaftaran yang meliputi formulir asli pengajuan izin operasional pendirian lembaga, surat pernyataan dari kepala lembaga, surat tanah milik atau wakaf, akte notaris yayasan/lembaga, data profil lembaga beserta jumlah santri dan guru, riwayat pengasuh atau kepala lembaga, dan susunan pengurus lembaga. Setelah data tersebut masuk kedalam aplikasi EMIS, maka dari pihak PD Pontren Kementerian Agama tingkat kabupaten akan melakukan visitasi, survey, dan verifikasi data untuk membuktikan bahwa lembaga tersebut benar-benar ada keberadaannya. Data yang sudah terverifikasi akan diajukan ke pusat untuk kemudian mendapatkan nomor statistic lembaga. Ketika suatu lembaga sudah mendapatkan nomor statistik, maka sudah bisa dipastikan bahwa lembaga tersebut terdata dalam aplikasi EMIS.15

Lembaga yang terdata di EMIS adalah lembaga yang sudah diakui keberadaannya serta Lembaga yang sudah terdata berhak memperoleh pelayanan dan pembinaan dari Kementerian Agama setempat. Ada beberapa pemanfaatan data Emis untuk Kementerian Agama kabupaten Tuban diantaranya yang pertama, dapat mengetahui jumlah lembaga yang ada di bawah naungan PD Pontren dan yang kedua dapat mengetahui rekap tenaga pendidik, tenaga kependidikan, dan data santri.

Peran EMIS sebagai sebuah sistem informasi manajemen pendidikan yang digunakan dilingkungan pendidikan diniyah dan pondok pesantren adalah sebagai sumber data yang dapat digunakan sebagai pendukung dalam pengambilan keputusan atau 
kebijakan dan juga dalam sistem pelaporan lembaga. Sebagai sebuah sistem yang telah dirancang dan dibiayai oleh negara, EMIS diharapkan mampu memberikan data yang akurat dan mudah untuk diakses, sehingga segala usaha yang telah dilakukan oleh Dirjen Pendidikan Agama Islam dalam melakukan pendataan pendidikan dapat dimanfaatkan dalam setiap pengambilan keputusan terkait dengan pendidikan dibawah naungan PD Pontren. Implementasi EMIS terutama yang berkaitan dengan pengambilan keputusan dan dalam sistem pelaporan yang membutuhkan data real itu seperti beberapa data untuk penentuan penerimaan sertifikasi guru, penentuan lembaga penerima bantuan seperti BOP (Bantuan Operasional Penyelenggaraan) dan BOS (Bantuan Operasional Sekolah), penentuan pemberian bantuan kepada santri atau dikenal dengan PIP (Program Indonesia Pintar), maupun pemetaan lembaga pendidikan dan guru yang ada didalamnya. Untuk sistem pelaporan Emis Kementerian Agama kabupaten Tuban khususnya dibidang PD Pontren yaitu melakukan pelaporan melalui data Emis setiap dua kali setahun/setiap semester. Sistem pelaporan tersebut juga berdasarkan pengambilan keputusan yang diambil dalam satu semester, kemudian keseluruhan data tersebut dilaporkan dipertengahan dan akhir tahun.

Pengelolaan data EMIS di Kementerian Agama kabupaten Tuban khususnya dibidang Pendidikan Diniyah dan Pondok Pesantren (PD Pontren) masih perlu adanya pembinaan. Karena banyak dari lembaga pendidikan islam yang masih belum paham fitur-fitur di EMIS dan juga masih banyak lembaga yang belum mengupdate data lembaga secara berkesinambungan. Hal ini disebabkan karena adanya beberapa faktor kendala, diantaranya yaitu: Adanya pergantian operator lembaga dan kurangnya Sumber Daya Manusia (SDM) yang cukup untuk mengerjakan EMIS, Sinyal internet yang tidak menjangkau semua wilayah, dan bahkan sering terjadi server eror, dan Jumlah lembaga Pendidikan Islam di kecamatan Tuban sangatlah banyak meliputi Pondok Pesantren, Madin Takmiliyah, Pendidikan Diniyah Formal, Pendidikan Kesetaraan Pondok Pesantren Salafiyah (PKPSS), Taman 
Pendidikan Al-Qur'an (TPQ), dan Muadalah. Sehingga pihak operator Kementerian Agama kabupaten Tuban di bidang PD Pontren tidak mampu memberikan pembinaan kepada semua operator, dan juga di sebabkan tidak adanya anggaran untuk melaksanakan kegiatan pembinaan.16

\section{Kesimpulan}

Berdasarkan hasil penelitian diatas, maka dapat ditarik kesimpulan sebagai berikut. Bahwa pemanfaatan Education Information Management System (EMIS) yang ada di bidang Pendidikan Diniyah dan Pondok Pesantren (PD Pontren) Kementerian Agama Kabupaten Tuban adalah sebagai acuan data dalam pengambilan keputusan dan sistem pelaporan lembaga.

Implementasi EMIS terutama yang berkaitan dengan pengambilan keputusan dan dalam sistem pelaporan yang membutuhkan data real itu seperti beberapa data untuk penentuan penerimaan sertifikasi guru, penentuan lembaga penerima bantuan seperti BOP (Bantuan Operasional Penyelenggaraan) dan BOS (Bantuan Operasional Sekolah), penentuan pemberian bantuan kepada santri atau dikenal dengan PIP (Program Indonesia Pintar).

Dalam sistem pelaporan EMIS Kementerian Agama kabupaten Tuban khususnya dibidang PD Pontren yaitu melakukan pelaporan melalui data Emis setiap dua kali setahun/setiap semester.

Adapun saran dalam penelitian ini adalah pihak Kementerian Agama Kabupaten Tuban khususnya bidang Pendidikan Diniyah dan Pondok Pesantren (PD Pontren) agar mengusahakan untuk mengadakan pembinaan atau pelatihan penggunaan EMIS, baik secara online maupun offline dengan tujuan supaya operator tingkat lembaga lebih mahir dalam penggunaan EMIS.

Diperlukan koordinasi yang lebih baik antara operator EMIS tingkat kabupaten Tuban dengan operator tingkat lembaga, terutama jika terdapat pergantian operator EMIS.

\section{References}


A, Rusdiana dan Nasihudin, Implementasi Kebijakan Emis Dalam Mewujudkan Akuntabilitas Pendidikan Tinggi Keagamaan Islam Swasta, Vol. 04 No. 07 November 2016

Azis, Fuadi, Pengambilan Keputusan Berbasis EMIS di Mapenda Kemenag Gunung Kidul, dalam Jurnal Pendidikan Islam, 3, 1 Juni 2014

Ditjen Pendis, 2009. Pedoman Mekanisme Pendataan Lembaga Pendidikan Islam.

Jakarta: Kemenag RI, hlm

Dr. Rukin, Metode Penelitian Kualitatif, ( Sulawesi selatan: Yayasan ahmar cendika Indonesia, 2019)

Hartono, Bambang, Sistem Informasi Manajemen Berbasis Komputer, (Jakarta : Rineka Cipta, 2013)

Wawancara bersama operator EMIS tingkat kabupaten Bapak Jariyanto pada 02 Oktober 2020, pukul 11.00 WIB di Kantor Kementerian Agama Kabupaten Tuban

Data diambil dari Aplikasi EMIS PD Pontren Kementerian Agama Kabupaten Tuban pada tanggal 25 Agustus 2020

Wawancara bersama Bapak Zainul selaku bagian pendataan PD Pontren Kementerian Agama Kabupaten Tuban pada 10 September 2020

Wawancara bersama Bapak Jariyanto selaku Operator EMIS tingkat Kabupaten di Kantor PD Pontren Kementerian Agama Kabupaten Tuban pada 10 Oktober 2020 